\title{
Malta: Language, Literacy and Identity in a Mediterranean Island Society ${ }^{1}$
}

\author{
CARMEL CASSAR, University of Malta
}

\begin{abstract}
Available documentation for the early modern period indicates that the Malta harbour towns achieved literacy earlier than the countryside. The Maltese townsmen lived on a trading route, and it was necessary for them to learn the lingua franca, as the language of trade in the Mediterranean. The educated élite were able to acquire fluent speaking knowledge, as well as the ability to write, Tuscan (a dialect then in the process of becoming standard Italian), while continuing to employ their local Maltese 'dialect' on numerous occasions. By and large, the erosion of the position of Maltese as the subordinate language was an inevitable by-product of this development. The Maltese language was able to attain the function of a literary language in the nineteenth century but it had no standard orthography until 1931 and was only adopted as Malta's official language in 1964.
\end{abstract}

\section{Oral Culture and the Uses of Literacy}

One of the most influential statements that equated language with nationhood was an essay by Johann Gottfried Herder (1744-1803), entitled Abhandlung Über den Ursprung der Sprache (Treatise on the Origin of Speech), published in 1770 after being awarded the essay prize of the Berlin Academy of Sciences. Herder argued that national feelings should be based on language, for in speech resides the nation's 'whole thought domain, its tradition, history, religion and basis of life, all its heart and soul. To deprive a people of its speech is to deprive it of its one eternal good ... With language is created the heart of a people'. ${ }^{2}$ In line with the spirit of the Enlightenment Herder believed that language had to be pruned and rendered more natural, since it was considered a social product, mutable and irregular, reflecting the progress of human society.

In Malta language, together with religion, has long been held to be the crux of Maltese identity and is often held to be the main differentiating mark of ethnic identity. Without doubt, the concept of a peculiar and distinctive language, such as Maltese, is often concomitant with the notion of a culturally autonomous community that reinforces it further. However until the late nineteenth century, on account of its Semitic base, the Maltese language continued to function solely as a local dialect. Indeed it only attained the function of a literary language when Malta began to culturally detach itself from nearby Italy. Until that stage was reached, Maltese held the same status as that of Italian dialects, while Italian froze into an official language on the same lines of Latin, useful for lyric, poetry and high culture, but unavailable to the majority of a society, still largely illiterate and economically backward.

This is not to say that there were no attempts at writing in Maltese before the nineteenth century. Indeed, poetry in a vernacular archaic form of Maltese appears 
around the $1480 \mathrm{~s}$ with the cantilena of Pietro Caxaro, a councillor of the Mdina Università (town council), ${ }^{3}$ described by one of his descendants as 'orator, poet and philosopher'. ${ }^{4}$

Presumably the cantilena of Pietro Caxaro, now hailed as the earliest poem in Maltese, represents a stage in Maltese society when no basic incompatibility existed between written and oral forms. As a matter of fact, Caxaro does not keep his poem free from the influence of oral modes. He starts his cantilena with a lament:

A recital of (my) misfortunes, $\mathrm{O}$ my neighbours,

the following I shall tell you,

Such as has not been found either in the

past or in your lifetime. ${ }^{5}$

Caxaro seems to have adopted a method of writing that was common practice in Medieval Europe, when literature was often intended to be recited aloud for the pleasure of a largely illiterate audience. The original composition may have been written down, but its transmission and main distribution was in practice oral. ${ }^{6}$

The practice seems to have been known in Malta and a casual reference to it is implied in the attribution to Thomasio de Abrami, an early sixteenth century non-Maltese grammar school teacher, of two such poems sung by boys in the streets of Mdina. ${ }^{7}$ A similar situation was obtaining in nearby Sicily. Helmut G. Koenigsberger reproduces a song which, 'amid other pasquinades', was sung in the streets of Palermo after the great famine of 1591. It would therefore appear that the singing of songs in the streets was a widespread practice in the Kingdom of Sicily. ${ }^{8}$

The mixed mode of literary distribution-popular song arising in part from a knowledge of written literature and transmitted by oral means, and intended to be recited, chanted or read aloud—was characteristic of Medieval Europe. ${ }^{9}$ Anthropological fieldwork has proved that similar situations can be met with throughout the world, particularly where a small educated and literate group interacts with the illiterate majority. ${ }^{10}$

The point regarding the importance of oral communications is worth emphasising, since written texts are our main sources of reference for the past and one is often tempted to overestimate written sources as a medium. We should remind ourselves that everyday communication was largely oral throughout the middle ages. Peter Burke remarks that,

much of popular culture long went unrecorded in writing, not only because most ordinary people were illiterate, but because the literate were either uninterested in popular culture, or ashamed of their interest, or simply unable to transcribe or transpose an oral culture in dialect into a written variety of the language. ${ }^{11}$

Within this framework, one notices that there existed two different types of culturethe written and the oral-that are often presented in contrast to each other with the result that the characteristics of oral and written traditions are normally studied in essentially opposed settings. This dichotomy is anticipated by Max Weber's view of society on the development of bureaucracy, and brilliantly expounded by Albert B. Lord in his study on Homer's Tales. It rests on the assumption that the essential formation of a society derives from its communication technology. ${ }^{12}$ In their studies on Yugoslav heroic poetry, Albert B. Lord and Milman Parry, suggest that epic singers composed anew each time they sang. This view has been profoundly influential in all 
areas of research on oral literature, and is taken as the basic point of reference in similar studies all over the globe. ${ }^{13}$ Indeed, it has been pointed out that in oral tradition, words could easily and deliberately be worked out in advance, or else, they may be improvised in the heat of the moment.

These theories, usually referred to as the 'Great Divide', were widely supported in the past, since they provided a highly rational concept of two opposing types of culture. However, various social scientists have questioned this view. It has been argued that in practice a mixture of media, oral and written, is far more typical of many societies, and therefore one cannot rely on just one form. In the vast majority of societies, writing is used for some purposes, and oral forms for others; this kind of mixture is and has been a common and ordinary feature of societies throughout the centuries, as Jack Goody succinctly sums up,

At least during the past 2000 years, the vast majority of the people of the world (most of Eurasia and much of Africa) have lived ... in cultures which were influenced in some degree by the circulation of the written word, by the presence of groups or individuals who could read or write ... even if one's attention is centred only upon village life, there are large areas of the world where the fact of writing and existence of the book has to be taken into account, even in discussing traditional societies. ${ }^{14}$

It is therefore clear that there has always been constant interaction between written and oral forms, which effect each other in the everyday transactions of any society. Ruth Finnegan has argued that one could not look for a clear-cut distinction between the two different forms, owing to the fact that oral and written traditions are diverse in their development and usage. ${ }^{15}$ Thus the medium of writing in itself cannot give rise to social consequences; it must be used by people and developed through social institutions. The mere technical existence of writing cannot affect social change. What counts is its uses, who uses it, who controls it, what it is used for, how it fits into the power structure, how widely it is distributed. It is these social and political factors that shape the consequences. Hence the implications of writing are different when strictly confined to an élite largely concerned with religion, in contrast to a society where there is widespread literacy. However, we are aware that widespread literacy is a very recent phenomenon, a consideration that induces Jack Goody to remark that 'mass literate cultures are the product of the last hundred years. It was the time when determined efforts were made to diffuse school education among all sectors of the population'. ${ }^{16}$

Seen in this light, Pietro Caxaro's cantilena stands out in contradiction to normal practice. Over 80 years later, when Luca D'Armenia (d. 1579), another prominent town councillor of the Mdina Università (town council), felt the need to express himself in writing, he chose to do so in Latin, the standard language of the educated classes. ${ }^{17}$ By then, Malta was more than ever firmly entrenched in the European camp thanks to the advent of the Hospitaller Order of St John in 1530. The position of the Maltese language might have deteriorated further due to the activities of the crusading Knights of St John against Muslims. An 'Arabic dialect', in the sixteenth century Catholic Mediterranean states, would have been looked down upon, as it would inevitably be associated with Islam. Nonetheless Francisco Nuñez Muley, a Morisco leader in sixteenth century Spain, who protested against unfair treatment of the Arabic speaking conversos, declared that 'the Egyptians, Syrians, Maltese and other Christian peoples speak, read and write in Arabic, and are still Christians as we are'. ${ }^{18}$

Possibly Muley's declaration could have applied for the fifteenth century, the time 
when Caxaro was writing his cantilena in Malta, but not to the sixteenth century when Malta had a crusading Order as feudal overlord whose raison d'être was to wage perpetual war against the omnipresent Muslim Turk.

Court records throw some light on singing habits among the common folk. The Maltese medievalist Godfrey Wettinger refers to fifteenth century Gozo-Malta's sister island-where young men often sang cantileni in the streets. ${ }^{19}$ This tendency seems to have been very common in pre-Reformation Europe, where youths were traditionally considered the custodians of village popular culture, largely equated with pre-literacy, with play, charivaris, non-conformity and pleasure. ${ }^{20}$

The Counter-Reformation, markedly present in Malta with the arrival of an Apostolic Visitor, Mgr Pietro Dusina, and the establishment of a Roman Inquisition Tribunal distinct from that of the Bishop in 1574, represented on the religious front a massive attack on the old 'popular culture'. ${ }^{21}$ Sung oral poetry or canczuni, seemingly popular even among members of the clergy, was especially targeted by the Holy Office. The Maltese Dominican friar Pasquale Vassallo was surely one of its victims. Vassallo wrote a couple of canczuni in Italian and Maltese, dedicated to several children in the later sixteenth century. The literature fell into the hands of other Dominican friars who denounced him for writing obscene literature. ${ }^{22}$

The enforcement of the rules of the Council of Trent must have led to a dramatic change in literary values, primarily because written literature came to be closely controlled by the Church authorities. ${ }^{23}$ Jean Delumeau asserts that there was an extraordinary interest in matters concerning religion among the reading public. PostTridentine Europe witnessed a renewal of scholasticism and theology. Besides, parishpriests were obliged to provide systematic religious instruction to children. ${ }^{24}$

The enfeoffment of Malta to the Order of St John accelerated the Italianisation of Maltese. Essentially, the active presence of the Order guaranteed not only a certain degree of political security, especially from Muslim incursions, but also very strong exposure, linguistic and otherwise, to continental influence. ${ }^{25}$ Culturally, the advent of the Order led to the island's adherence to the recognised canons of the Renaissance which the Knights introduced in all forms of cultural expression. ${ }^{26}$ Such a distinctive trait was noticed by contemporaries as early as 1557 , when it was reported that since the arrival of the Order, people at Birgu were mixing lo vulgare italico with Maltese, due to the admixture of local people with immigrants from Italy. ${ }^{27}$ By then, Italian had already established itself as the cultural high language of Malta. The Maltese linguist Joseph Brincat deduces that, in the late Middle Ages, 'the Church, since it spread everywhere and in all social strata, was certainly the first and main channel of Romance terms on account of its frequent relations with Neo-Latin Sicily' ${ }^{28}$ Indeed the earliest surviving document written in Italian dates back to $1409 .{ }^{29}$ In such a situation it was natural for Italian, later in its Tuscan form, to develop as the main language of communication. Yet, up to the end of the eighteenth century, the Maltese language was practically the exclusive language for daily communication used in the countryside, and to a large extent it continued to be employed by the townspeople too. It was spoken by people of all social conditions, including the learned and the rich. ${ }^{30}$

The case of Dr Melchior Cagliares, a well-known sixteenth-century judge of the Grand Master's court, who took the Grand Master's side in a quarrel between his master and the reigning Bishop, Tommaso Gargallo, is a case in point. Cagliares was excommunicated by the Bishop, so that no good Catholic was supposed to have dealings with him. The Inquisition records refer to Cagliares' reaction to this sentence. When the Rector of St Paul's Parish in Valletta, presumably a friend of his, one day 
failed to greet the Judge whom he encountered in the town-square, Cagliares called out in Maltese: Le tibzax hecde kif fixkilt lohrayn infixkil lilik (Do not worry, I will confound you as I did others). ${ }^{31}$

Thus, even the Maltese educated élite communicated in the local tongue between themselves. At the same time, Maltese was often associated with ordinary people and popular culture. Hence, official documentation for the late Middle Ages, available in public and private archives, is invariably written in Latin and Sicilian. From the sixteenth century onwards, these were mostly transcribed in Latin and Tuscan Italian. ${ }^{32}$ Such a situation created difficulties in a number of cases.

Problems were bound to rise in connection with the making of contracts, particularly when one or both parties concerned could not understand any of the official languages. The Maltese historians Godfrey Wettinger and Michael Fsadni give a number of references to demonstrate that the language of the late medieval and early modern Maltese was beyond doubt Maltese. Among the most valuable instances, they cite the case of the Benedictine monks of Catania who, as early as 1364, refused to set up a monastery in Malta because, amongst other objections, they did not know the language of the islanders.

Lack of knowledge of Maltese continued to be considered a severe handicap to clerical appointments during the late sixteenth century. It was for this reason that members of the Università protested, in December 1592, at the permanent conferment of eight benefices to the Jesuits who at the time had agreed to open a college in Valletta. The council members pointed out that 'for the comprehension of confessions, and in order to preach to the people, and to teach their children, it is indispensable that the confessor, the preacher and master should understand well and know the language of the confessants, hearers and pupils'. ${ }^{33}$

Other professions were also similarly affected. In 1584, Dr Giovanni Calli, a Civil Court judge, asked the then reigning Grand Master, La Cassiére, to appoint Gioan Paolo Micci as his substitute to hear minor cases on the grounds that Micci knew Maltese much better than himself. ${ }^{34}$ A similar argument was put forward by Gioan Domenico Mangion in 1596; he asked to be transferred, as the salaried doctor of the Mdina Università, on the grounds that 'as he is Maltese, he knows and could speak Maltese, the language spoken by all those of Mdina and Rabat'. ${ }^{35}$

Here, Mangion tends to emphasise the existing urban/peasant dichotomy which became even more marked in the centuries that followed. So that, while in the Harbour area, it became relatively easy for people to understand each other utilising a lingua franca, the peasants of the surrounding countryside could only understand and speak Maltese. ${ }^{36}$

\section{The Lingua Franca and Italian}

Population shifts, and the continual increased rhythm of trade and communications made it necessary for the urban dwellers in the Harbour area to acquire the lingua franca which, in the early modern Mediterranean, consisted primarily of Italian words.

It is at this point worth examining the use of lingua franca in the Mediterranean. Manlio Cortelazzo focuses on three types of lingua franca: the Berber Sabir-a language of exchange used in North African Maghreb countries; Colonial Italian-consisting mainly of Venetian and/or Genoese idioms, widely used in the colonies of the two maritime republics; and the lessico mediterraneo which has sometimes been said to 
represent primarily a nautical jargon. ${ }^{37}$ Cortelazzo stresses that lingua franca was widespread among the lower classes of the urban agglomerates, where the élite generally managed to be perfectly bilingual. ${ }^{38}$

Louis Coutelle argues that the lessico mediterraneo in Greece developed partly thanks to the presence of a merchant navy, continuously in touch with the French, Venetians and the Genoese. The use of lingua franca, with a neo-Latin base, helped to strengthen communications between Greece and the West European states. In reality, the Greeks had already been in close contact with the West due to centuries of colonisation by 'Franks' of different linguistic background-Catalans, Provençals, French, Venetians and Genoese, all present both on the mainland, and in both the Aegean and the Tyrrhenian seas. The presence of western corsairs, including the Knights of St John, hailing from all parts of Europe, enabled the Greeks to acquire some knowledge of various European languages. All these factors, stresses Coutelle, contributed towards the widespread use of lingua franca in the region. ${ }^{39}$

Most elements adopted by Coutelle for Greece appear also to be relevant for Malta following the advent of the Order of St John. The Knights kept strong communications with Europe and strengthened both the merchant fleet and the navy. At the same time, Malta served as a base for corsairs against the Muslims of the Maghreb and the Turks in the Levant. Finally, one should include the multitude of foreign men who contracted marriages with Maltese women, notably in the Harbour towns. It was therefore natural for the early seventeenth century Maltese courtesan Margarita Bonnici of Vittoriosa, to refer to the herb she used for a love potion both in Maltese and in franco. ${ }^{40}$ Concurrently Minichella de Patti from Vittoriosa apparently communicated with her French husband Antonio Gontier in Italian. ${ }^{41}$

'Italian' was then the language of trade in the Mediterranean which in the Maltese Harbour towns spread at the expense of Maltese, then reduced to the status of a local dialect spoken by servants, peasants and the lower orders of society. By the late eighteenth century, this jargon seems to have developed into what in 1796 the Maltese linguist Mikiel Anton Vassalli (1764-1829) labelled, dialetto della città (city dialect), which he considered as the most corrupt dialect of Maltese, due to the large number of foreign words it contained. The presence of a great number of foreigners, as well as the use of foreign languages, notably Sicilian, Italian, French and other European vocabulary, led to barbarizzare l'idioma nativo (the 'barbarisation' of the native idiom). ${ }^{42}$

This development induced Vassalli in 1796 to insist on the social need to cultivate $l a$ lingua nazionale (the national language). Vassalli reflected upon the attitudes of his times and admitted that Maltese seemed undignified and abounding in 'barbarisms' which, he concluded, were the result of the long neglect of the language. Vassalli's ideal perspective of a defined Maltese culture and language, was to take root over a century after his death. His dream of Maltese consciousness could only materialise with the widespread use of literacy.

At the end of the eighteenth century, a little before Vassalli put ink to paper, very few Maltese could read and write and this seems to have been more evident in the rural areas. For instance, at Qormi in 1773, out of 226 heads of households, only 22, or 9.7 per cent, could sign their name. ${ }^{43}$ And a signature does not qualify an individual as literate. Written works were accessible only to the educated few, the majority of whom were clerics. Hence, in spite of the theoretical existence of writing and printing, only a limited élite could fully utilise the written word. ${ }^{44}$ The net result was that oral culture continued to dominate the scene at least until the early nineteenth century. ${ }^{45}$ Malta, like 
the rest of the Mediterranean, possessed a definite literary class whose compositions were often transmitted to the illiterate mass of the population in oral form.

The differentiation into high culture (written) and low culture (oral) was not simply a cultural division, that created also a distinction between two kinds of work. Administrative, academic and professional work could only be aspired to through the acquisition of a literary education; manual work required considerable experience in the craft performed. Thus writing created a radical distinction between the literate and illiterate elements of society.

In the end, the kind of knowledge obtained from the literary tradition tended to be more highly valued than the practical knowledge and experience acquired by some form of manual participation. Hence written literature was considered to be the highest form of expression, even though oral culture remained the only accessible form of expression for the majority of the people. The frequent promulgation of bandi (edicts), which were read out aloud in town and village streets for the information of those present, was the only official way news filtered to the masses. In such circumstances, literacy comes to be considered as the established and respected tradition, while orality is transformed into a living art.

In spite of this, there existed a fundamental tension between written and oral cultures. The literate élite was increasingly inclined to have recourse to the written word both in the public and private spheres; oral traditions were based 'on nostalgic and utopian esteem for a society without writing, governed by words that everyone could hear and signs that everyone could understand'. ${ }^{46}$

\section{Élite and Popular Cultures}

It has often been argued that whatever cultural divergences existed between social groups, medieval Europe shared a common culture. The story-tellers of the Middle Ages were precious messengers and intermediaries between the oral culture of the illiterate masses and the literature of the educated strata. ${ }^{47}$ Aron Gurevich argues that until recently 'the legend of the "Christian Middle Ages" ... as an epoch under the absolute and complete dominance of Catholic ideology was unshaken' ${ }^{48}$ Gurevich rather opines that clerical culture did not so much replace as restructure popular culture. ${ }^{49}$

Nevertheless, Christianity appears to have affected the values of medieval culture at large. In medieval Iceland 'conversion to Christianity entailed an explicit model of englobement of differing societies into one "international" system', says Kirsten Hastrup. She concurs with Keith Harrison that the Church seems to have conquered the Nordic heathens by 'teaching them to read and write', and by 'enshrining their ways of life within a Roman casket'. ${ }^{50}$

Perhaps the same argument might explain why the fifteenth century landowner, Pietro Caxaro, opted to write in Maltese at a time when the élite group preferred to communicate in Latin or Sicilian. Peter Burke suggests that the distinction between learned and popular culture already existed in the Middle Ages, as is indeed illustrated by Caxaro's case, but the two cultures grew further apart in the sixteenth century. ${ }^{51}$

Oral transmission has often been portrayed as characteristically present in societies anchored to a pre-industrial economic system. However, as Max Weber remarks, literacy has often been associated with civilisations characterised by the development of urban and bureaucratic systems, as well as by the rise of secular and scientific enquiry. ${ }^{52}$

By the sixteenth century, two distinct separate cultures came into being: an 'élite' and 
a 'popular' culture. Élite culture was subject to changes in style: Renaissance, Mannerism, Baroque, Rococo. It was basically academic and professional as well as recondite and expressive. It included the superior sort of painting, sculpture, chamber music, choice theatrical entertainment, as well as a written literature which required an educational basis to be appreciated.

After the Order of St John moved into its new city, Valletta in 1572, it became possible to establish a ceremonial and sumptuous existence compatible with the tenor of the times. The foundation of the new city (1566) and the concomitant flourishing of architectural and artistic activities brought about a peculiar aesthetic atmosphere where at first Mannerist sensibility predominated. The Italian Francesco Buonamici had in the course of the 1640s introduced Baroque architecture to Malta, but the local school of civil engineers, including Tommaso Dingli (1591-1666), held their ground for yet another third of a century. ${ }^{53}$

Likewise, Maltese art remained heavily influenced by Mannerist painters, until the mid-seventeenth century, in spite of the fact that between July 1607 and October 1608, Malta benefited from the presence of Michelangelo Merisi da Caravaggio. ${ }^{54}$ Thus mannerist influence continued to dominate art until the arrival of the Calabrian painter Mattia Preti (1613-1699) who settled in Malta from 1661 until his death. ${ }^{55}$ The new style received encouragement from the Order, since it became identified with a wide Catholic movement of thought. ${ }^{56}$

The Maltese élite was also prolific in baroque literature, mostly written in Latin and Italian. Amongst these writers, the best known was Gian Francesco Abela (1582-1655) who studied law at Bologna University, and is now considered as the father of Maltese historiography; Domenico Magri (1604-1671), a well versed scholar in Biblical and Semitic studies; and Giovan Francesco Bonamico (1639-1680). ${ }^{57}$ One could also notice a general improvement of musical standards particularly in church music. ${ }^{58}$

By the late seventeenth century, life in Valletta had a much more worldly appearance than ever before. A popular feast, in which the élite participated fully, was that of Calendimaggio. The feast of Calendimaggio originated in Italy and attained great popularity in Malta by the early eighteenth century. ${ }^{59}$ The annual feast was held in the afternoon of 30 April in the Palace square at the heart of Valletta. For this occasion, the élite organised theatrical representations, serenades and cantatas eagerly watched by the Grand Master himself. These performances were also widely popular among the lower classes that attended in large numbers. However it appears that the latter watched the spectacle passively and took no active part in the events. ${ }^{60}$

The erection of the Manoel theatre in 1731-1732 further multiplied the social events held primarily for the élite. Besides plays, operas, and chamber music, Carnival balls were also held at the theatre. Probably, as pointed out by the Maltese folklorist Joseph Cassar-Pullicino, Il-Maltija, the Maltese 'national' dance, was introduced as a court dance during the later years of that century, since even now the dancers still tend to wear an eighteenth century costume. ${ }^{61}$ In contrast to the refined and spectacular activities of high culture, popular culture continued to uphold traditional values based on the spoken word, primarily expressed in songs, poems, stories and other artefacts of popular cultural entertainment. In short by the eighteenth century the élite, as in most parts of Europe, comprising landowners, clergy, merchant and professional classes, 'had abandoned popular culture to the lower classes, from whom they were now separated, as never before, by profound differences in world view'. ${ }^{62}$ 


\section{Maltese versus Italian}

Malta of the Knights Hospitallers had been truly integrated into the general European culture of the times. As in other pre-industrial European societies, languages got diffused or contracted according to the change in the trade patterns in the Harbour area. Joseph Aquilina points out that the Normans probably introduced Sicilian, which by the fifteenth century became, together with Latin, the official language of Malta. ${ }^{63}$ Italian, in its Tuscan form, had established itself as lingua franca around the midsixteenth century, 30 years or so after the advent of the Hospitaller Order of St John. It remained thus entrenched throughout the Order's rule among the cultural élite, especially in the seventeenth and even more so in the eighteenth century. ${ }^{64}$ The situation is expressively summed up by Dr Francesco Saverio Farrugia, a Councillor of the Supreme Tribunal of Justice in the mid-eighteenth century. Not only did Farrugia write in Italian, he even referred to that language as lingua materna (mother tongue). ${ }^{65}$ Farrugia's declaration seems too imply further the separation of upper-class and lower-class cultures, a trend most clearly experienced in most West European states of the eighteenth century. Farrugia's cultural perception suggests that besides adopting more 'polished' manners, and a new self-conscious style of behaviour, the élite began to speak a different language from ordinary people. Furthermore, Farrugia's assertions indicate that Italian gradually became the dominant language 'of convenience', the language of the powerful, and of the Court, slowly infiltrating many areas of public life. In short, Italian had therefore strongly become entrenched as the standard language of cosmopolitan Malta, while the local 'dialect' and idioms remained the predominant medium of communication in the countryside and the everyday parlance in the towns. ${ }^{66}$

Yet as early as the 1640 s, Gian Francesco Abela had already remarked that the Maltese were by then losing their native tongue. He pointed out that, it can be expected that one day they will lose it completely since even the unlettered are using so many Italian words in their speech'. ${ }^{67}$ In the course of the seventeenth century, Tuscan Italian had firmly entrenched itself as the literary language of the Italian peninsula. Since culturally Malta was in Italy's sphere, it became more urgent for the élite groups to acquire the dominant language. In this way, Italian continued to intrude more and more into the domains of life and to assume more functions. The widespread use of romance European languages, instead of Maltese, is stressed by the French traveller Sieur Du Mont, who stopped at Malta for some days in June 1690; 'There are three languages spoken in the city; the French, Spanish and Italian. The last of these is authoriz'd by the Government and used in publick Writings. The peasants in the country speak a corrupt dialect of the Arabic: and t'wou'd not be an easie task to make 'em leave it ...' ${ }^{68}$

Possibly Du Mont meant that the inhabitants of the Harbour area could understand, and possibly speak, some phrases in French, Spanish and Italian. More likely, this was some form of lessico mediterraneo which Cortellazzo considers to have been widespread among the lower classes of the urban agglomerates. ${ }^{69}$

The Maltese language was less current in the cultural, administrative and business centre of the island, that is, in the Harbour area, partly due to the growing presence of immigrants from abroad, who married and established themselves there, partly due to the presence of a large mercantile class, apart from the fact that the administrative class itself hardly knew any Maltese.

In the mid-eighteenth century the Maltese linguist and folklorist Canon Agius De Soldanis (1712-1770) observed that the Maltese of Valletta and the Harbour area still 
spoke Maltese amongst themselves, but Italian was the current language they used in communicating with foreigners; however, in the villages, or casali, the nazionali (nationals) used Maltese throughout, which they learnt from their parents. ${ }^{70}$ Inspired by the revival of interest in Etruscan, Agius de Soldanis justified his eagerness in establishing an alphabet for Maltese, partly to enable scholars to learn ancient Punic. It had also to serve as a grammar for the nazionali, as well as forastieri (foreigners), particularly professed Knights of St John. ${ }^{71}$

By 1796, Mikiel Anton Vassalli was complaining that the dialetto della città (the city dialect) - the kind of Maltese spoken in the Harbour area-included a large number of words derived from Sicilian, Italian, French and other foreign European languages. In other words, by the late eighteenth century, the diglossia, that had prevailed in the Harbour area throughout the Order's rule, had become the common tongue with educated Maltese - a fact that Vassalli viewed with concern. ${ }^{72}$

The few Maltese who were ever knighted came from the Italian speaking élite and would not be bothered to speak or write in Maltese. They used Maltese among themselves as a sign of familiarity and domesticity. Frequently, as the Italian knight Count Camillo Spreti recalled in 1764, they would speak Maltese in front of the foreigners so as not to be understood. ${ }^{73}$

The same pattern seems to apply for Maltese where there was no policy of linguistic unification, where Italian gradually became the dominant language 'of convenience', the language of the powerful, and of the Court, gradually infiltrating many areas of public life. Italian had therefore become strongly entrenched as the standard language of cosmopolitan Malta, while the local 'dialect' and idioms remained the predominant medium of communication in the campagna (countryside) and in the everyday parlance of the towns.

Italian continued to reign supreme as the principal official language of Malta both in private and official correspondence well into the nineteenth century. ${ }^{74}$ Thus, although the Italian language grew in importance, both Maltese and Italian continued to have clearly marked domains of usage. And it was only at the end of the eighteenth century that the Maltese language began to be seen as a symbol of nationality; it thus started to be used as a focus of political, as well as cultural aspirations. ${ }^{75}$

Up till the eighteenth century, the Maltese language functioned as a local dialect, employed-according to the Maltese historiographer Gian Francesco Abela writing in 1647-by gente idiota (simple folk). Abela argued that Italian and Latin had been used in the Maltese courts and tribunals for about 500 years. Abela's main aim was to accept the obvious by acknowledging Arabic linguistic influence on the island. Nevertheless, he simultaneously minimised this fact, by pointing out that the same had occurred in Sicily. Maltese was nearer to Arabic than Sicilian due to the relative isolation of Malta. ${ }^{76}$ Such argumentation evinces the unease of Abela- a highly erudite member of the élite, and Vice-Chancellor of the Order of St John - when confronted with the language question.

Indeed during the seventeenth century, the Maltese language was completely disregarded as a vehicle of culture. Gian Francesco Bonamico's poem which-before the discovery of Pietro Caxaro's cantilena in 1968-had been hitherto considered as the first poem in Maltese, is a case in point. No other poem written in Maltese by Bonamico has survived and it is doubtful whether he wrote any other. Abela, Magri and Bonamico were perhaps the best representatives of 'élite culture' in seventeenth century Malta, and all three savants expressed themselves in Italian. ${ }^{77}$

Bonamico had already tried his pen in Latin and Italian before he wrote his sonnet in Maltese dedicated to Grand Master Cottoner around 1675. This sonnet was written 
in Maltese in order to be recited in the central square of Valletta during the popular feast of Calendimaggio. ${ }^{78}$ The fact that it was intended for a popular feast, which the common folk attended in great numbers, explains why it was written in Maltese-a language which was understood by the mass of the local population, even though the style of this Maltese sonnet clearly recalls Italian lyrics of the times. It is evident that Maltese culture at the time followed Italian culture so closely that it could be said to have formed part of the literary tradition of Italy. ${ }^{79}$

That this development gained momentum in the seventeenth century is also significant. That century saw the establishment of a printing press in Valletta, and although it functioned for a relatively short period, due to the intervention of the Inquisition, a number of publications, including Della descrittione di Malta (1647) by Abela, were issued in both Latin and Italian.

The existence of a printing press, like the presence of a literary class, must be seen within the context of the times. As in other pre-industrial societies, writing in Malta served precisely to uphold the current authority structure and prevent dissenting views. Bonamico was instrumental in praising the benign rule of Grand Master Cottoner at a popular feast. His gesture of writing a sonnet in honour of the ruling prince was typical of a good and loyal educated subject of any other early modern European state. Perhaps Bonamico was trying to seek the favours of the ruler, but the poem definitely reflects a mentality typical of Europe in the pre-French revolutionary period. It ties up neatly with N. Postman's observation that 'writing can provide a road to new forms of self-advancement, but it can also be used for control in the interests of those with power over writing and written sources' ${ }^{80}$ But this is not to say that everything in scientific and cultural development depends primarily on writing. As with any other skill, the effectiveness of writing depends on how it is actually used, as well as its interplay with other forms of communication.

As has already been indicated, literacy does not always lead to objective enquiry, a conclusion easily applicable to early modern Malta. Thus while the chroniclers of the Order of St John, like Iacomo Bosio, Bartolomeo Dal Pozzo, the Abbé de Vertot and others wrote about the glorious past of the Order, Gian Francesco Abela wrote in order to boost the image of the Maltese land owning class, while Bonamico made use of the local speech to praise the benign rule of the then ruling Grand Master.

On other occasions, writing was used to interfere with objective scientific or historical enquiry. It has already been shown how the Inquisition managed to acquire complete hegemony over the spread of the printed word by the end of the sixteenth century. ${ }^{81}$ Its massive influence explains why a printing press was set up at so late a date in Malta, and why its lease of life was so short.

Writing could thus have been employed to preserve traditional culture, even to lend it a new lease of life, such as boosting the Pauline tradition and the survival of Christianity throughout the ages, as maintained by Gian Francesco Abela. ${ }^{82}$ Indeed much of what is called 'oral tradition' is known mainly because it has been recorded and circulated in writing. Writing, the existence of a permanent and unchanging record over time, took root and asserted itself as 'immemorial custom'. ${ }^{83}$ A situation was created where, to be a good and loyal subject, one was also forced to believe in the myths and beliefs of one's own society.

\section{The Emergence of Maltese as a National Language}

The equating of language with national sovereignty was taken up by the Jacobins at the 
time of the French Revolution. The Jacobins, inspired by the Enlightenment which preceded the revolution as well as the ideas of Herder, insisted that the French nation must be united around the French language, at the expense of any other languages or dialects that had survived within the French borders. Their view continues to this day to exert great influence on the French attitude as to the relationship between language and the state. ${ }^{84}$

Such liberal views, of obvious French import, were diffused throughout Europe, and in the case of Malta by the French community, particularly by French Knights and entrepreneurs ever since the early eighteenth century. The survival and discovery in an Italian library of a dictionary of Maltese and its associated little grammar recently attributed to the French knight Thezan, probably written sometime in the seventeenth century, is evidence that for quite several decades before Agius de Soldanis, others, amongst them even some non-Maltese, had already performed some sustained work on the Maltese language, realising the need to communicate by utilising the native language of ordinary people. ${ }^{85}$ Indeed, Agius de Soldanis referred to two grammars which preceeded his own, although he complained that nulla s'è veduto (they are not available). One of these grammars is attributed to Mgr Xeberras, Bishop of Eufemia and member of an old Mdina family; another one was attributed to the French knight Touron who in 1750 had taken up residence in France. ${ }^{86}$

Yet in Malta, it was primarily Mikiel Anton Vassalli-born in Zebbug in the middle of the countryside - who as early as 1796 had insisted on the social need to cultivate the lingua nazionale (national language) which for him was Maltese, and not Italian. ${ }^{87}$ Vassalli studied in Rome at a time when the Eternal City was still one of the important cultural centres of Europe. While in Rome, Vassalli must have been influenced by Herder and the Jacobins. There he published some of his works and imbibed liberal ideas, particularly the principles of popular participation in culture and democratic diffusion of knowledge.

In the spirit of Herder, he envisaged Maltese as a unique and most useful document of the island's antiquity, worthy of the scholar's objective research and of the cultured people's refined adoption. ${ }^{88}$ Having arrived at a sort of political programme for Malta in the light of his experiences abroad, he considered Malta as a spiritual and physical organism, the centre of interests wherein individuality is acquired through the recognition of a national tradition, history, culture and above all, language. ${ }^{89}$

Vassalli also seems to have been influenced by the Abbé Grégoire (1750-1831), a French Catholic priest and revolutionary, who supported many of the liberal ideas of his day. Amongst them was the reform of the Church, the emancipation of slaves, the development of a compulsory, free, primary system of education, and the universalisation of the French language, themes which were adopted by Vassalli for the Maltese context in his introduction to the Ktyb $y l$ Klym Malti published in Rome in $1796 .{ }^{90}$

Thanks to Vassalli, a well-formed vision of a national language made its appearance. It was based on the concept that Maltese could perform the role of both an official language of the state, and as a medium for literature. This was a new concept for the term 'nation', which in earlier times was confined to the 'conscious and active part of society'. ${ }^{91}$ During the French Revolution, 'nation', 'state' and 'language', became identified and there was a demand for the 'ethnicisation' of the polity. ${ }^{92}$ Thus language came to be seen as a powerful tool in the hands of nationalists, although it was not the only one, a fact clearly explained by A.B. Philip who argues: 'It is an accepted wisdom that nationalism needs to be buttressed by certain key factors which distinguish one 
nation from another. Among these factors are counted a common territory, a common language, a common culture, a common history and a common religion ...' ${ }^{93}$

The statement tends to emphasise the existence of a common belief about ethnic groups having some kind of natural right to autonomous national status. In short citizenship was based, above all, on terms of a common cultural background and juridical status. Indirectly nationalism can also be seen as a consequence of printing or as Benedict Anderson succinctly points out, 'the convergence of capitalism and print technology on the fatal diversity of human language created the possibility of a new form of imagined community'. ${ }^{94}$ Furthermore Anderson argues that the 'choice' of language appears as a gradual, unselfconscious, pragmatic, not to say haphazard development. Thus, 'for essentially administrative purposes these dynasties ... settled on certain print-vernaculars as languages of the state-with the "choice" of language essentially a matter of unselfconscious inheritance or convenience'. ${ }^{95}$

It is thanks to the printing of books in the national language, by Vassalli, and the nineteenth century authors that followed him, that it became possible to turn the 'vernacular into an extensive mass medium'. ${ }^{96}$ With this perception in mind, Carlo Cipolla considers the increasing literacy that came with print as a precondition: 'Had literacy remained the well-guarded monopoly of a few mandarins, European society could hardly have developed in the way that it did'. ${ }^{97}$ Through this development, the medium of communication, unavailable to Vassalli, was eventually provided to his successors by the British Colonial authorities when they conceded liberty of the press to the Maltese in 1839 .

It would perhaps be useful to conclude with a comment on the role played by the Maltese language in the functioning of identities. However, such a view must be understood within the perspective of Malta's geographical position and her role as a frontier society between Christianity and Islam. It is obvious that such conditions left an indelible mark on the development of the Maltese language. In fact Maltese is essentially a Semitic language, with close affinity to Arabic, and it was therefore often associated with Islam. ${ }^{98}$ Malta's relative isolation from continental Europe, and its role as an auxiliary base of nearby Sicily, induced the island to remain culturally Sicilian throughout the later Middle Ages. The advent of the Order of St John in 1530 can be considered as an accidental change of rule which brought to Malta's shores a much higher level of civilisation and a far more complex European way of life. Malta of the Knights imbibed Italian and French cultural tastes thanks to the presence of a large number of non-Maltese in the Harbour area. As has been stated above, the new cultural atmosphere induced the locals to adopt Italian as lingua franca and this helped transform Malta into an area courant with happenings in the major cities of Europe. This inevitable twist of fate acted as a 'stimulus for the Maltese to come to terms with themselves', by helping them to mature while outlining their rights and expectations as an ethnic community. ${ }^{99}$ However it was during the nineteenth and twentieth centuries that the use of language came to play a fundamental role in the functioning of identities in Malta.

The essence of Maltese ethnic awareness was enhanced during the short spell of French occupation (1798-1800), culminating in an insurrection against the French administration, an awareness which was further intensified throughout the British colonial period (1800-1964) that followed. The turning point of the British occupation of Malta came with the opening of the Suez Canal in 1869, with the unification of Italy and Germany in 1870-1871, and subsequently by the expansionist policies of the great powers in the Mediterranean. Coupled with Malta's growth in strategic importance, as 
a station linking Britain to her most important colony, India, the colonial government changed from a relatively stable, easy-going affair into an intrusive and authoritarian rule-a condition which heightened, indeed provoked, the clash between Anglicisation and Italianisation. ${ }^{100}$

With this turn of circumstances, the study of English was privileged, while an anti-Italian bias marked routine government administration. In the long run, Italian unification itself proved detrimental both to those Maltese who sympathised with the Italian culture, and to the fate of the Italian language in Malta. Maltese political leaders found themselves divided into two camps - the pro-British and the pro-Italiansengaged, as they were, in a conflict between civil rights and military needs. ${ }^{101}$

The campaign for Anglicisation was spear-headed by Sigismondo Savona (18371908), a former sergeant-major and schoolmaster, precipitously promoted, first to Rector of the Malta University, and then to Director of Education. In Savona's opinion, Malta needed to be anglicised for the benefit of the workers seeking employment both in government service and the Armed Forces. This approach was eagerly advocated by the Cambridge-trained lawyer, Lord Strickland (1861-1940), the son of an English naval captain and a Maltese lady of aristocratic antecedents.

The pro-British party thus came to regard the Italian language as a great obstacle, arguing that the language of Malta was Semitic rather than Italian. Taking up where Savona had left, Strickland stressed the need to instruct the Maltese in native Maltese and in English, pointing out that both languages were necessary for the amelioration of working class conditions. He went so far as to postulate that the Maltese were descended from the Phoenicians. ${ }^{102}$ Strickland associated the Maltese with the ancient Phoenicians simply because the 'Arabisation' of Maltese was strongly opposed by all sectors of Maltese society. It was then a common assumption that Arabic heritage was synonymous with Muslim civilisation, a culture that had no place in any prototype of Christian Europe. Hence Strickland was left with no choice but to suppress this reality and propagate a Phoenician ancestry for the Maltese.

After the Second World War the place reserved for Italian between the wars was now taken up by Maltese, originally strongly opposed by the pro-Italian nationalists, since it had been paradoxically instrumentalised by the British as a medium of instruction to favour the spread of English faster and easier. Indeed until 1931 Maltese had no standard orthography and it only came to be accepted as the official language of Malta with the adoption of the Independence constitution of 1964. After independence English became officially a second language, while the influence of Italian has been retained mainly through strong cultural ties and the diffusion of Italian television channels that have a strong following among the better-educated sections of the Maltese community. The clash between Maltese, English and Italian during the late nineteenth and early twentieth centuries, when one language was able to supplant another, is in my view, a strong indication that language, like descent, remains a problematic concept to define identity.

Correspondence: Carmel Cassar, 73 'Nirvana' Parilja Street, Santa Venera, HMR-16, Malta. e-mail: ccas1@um.edu.mt

\section{Notes}

1. Earlier versions of this article were presented as a Public Lecture at the University of Wales, Lampeter and as a seminar at the Linguistic Circle, University of Malta. I am very grateful for both audiences for their helpful comments and suggestions particularly Keith Robbins, Fiona 
Bowie, Manwel Mifsud and Albert Borg and to Peter Burke for his encouragement during the writing phase.

2. Ronald Wardaugh, Languages in Competition. Dominance, Diversity, and Decline (Oxford: Blackwell, 1987), p. 54.

3. Mdina, also known by the honorific title of Notabile, is the old town of Malta and the seat of the medieval municipality of the island.

4. Brandano Caxaro's introduction to the poem in Godfrey Wettinger and Michael Fsadni, Peter Caxaro's Cantilena. A Poem in Medieval Maltese (Malta: Lux Press, 1968), p. 38; Wettinger and Fsadni, L-Ghanja tà Pietru Caxaru. Poezija bil-Malti Medjevali (Malta: Printwell, 1983), p. 47.

5. Wettinger and Fsadni, Peter Caxaro's Cantilena, p. 38.

6. R. Crosby, 'Oral delivery in the Middle Ages', Speculum, 11, 1936, pp. 88-90.

7. Godfrey Wettinger, 'Looking back on the "Cantilena" of Peter Caxaro', Fournal of Maltese Studies, 12, 1978, p. 98; cf. C(athedral) A(rchives) M(dina), C(uria) E(piscopalis) M(elitensis), A(cta) O(riginalia), vol. 8A, p. 38.

8. Helmut Georg Koenigsberger, The Government of Sicily under Philip II of Spain (Ithaca, NY: Cornell University Press, 1951), pp. 206-207.

9. Aron Gurevich, Medieval Popular Culture: Problems of Belief and Perception, English translation (Cambridge: Cambridge University Press, 1988), pp. 3-6.

10. Ruth Finnegan, Oral Poetry: Its Nature, Significance and Social Context (Cambridge: Cambridge University Press, 1977), p. 167.

11. Peter Burke, 'Introduction', in Peter Burke and Roy Porter (eds), The Social History of Language (Cambridge: Cambridge University Press, 1987), p. 10.

12. Albert B. Lord, The Singer of Tales (Cambridge, MA: Harvard University Press, 1960), pp. 6-7, 124-38.

13. Ruth Finnegan, Literacy and Orality (Oxford: Blackwell, 1988), pp. 12-14.

14. Jack Goody, 'Introduction', in Jack Goody (ed.), Literacy in Traditional Societies (Cambridge: Cambridge University Press, 1968), pp. 4-5.

15. Finnegan, Literacy and Orality, p. 175.

16. Goody, The Interface between the Written and the Oral, p. 164.

17. Luca D'Armenia wrote a poem, which he entitled Ad Patriam, on the eve of the Ottoman Siege of Malta in 1565. The poem, discovered by the present writer in 1981, was found in a volume of petitions to the Grand Master of the Order of St John and de facto ruler of Malta. See: Carmel Cassar, Society, Culture and Identity in Early Modern Malta (Malta: Mireva Publications, 2000), especially p. 289.

18. Henry Kamen, Inquisition and Society in Spain in the Sixteenth and Seventeenth Centuries (London: Weidenfeld and Nicolson, 1985), p. 108.

19. Wettinger, 'Looking Back on the "Cantilena", p. 89.

20. Daniel Fabre, 'Families: Privacy versus Custom', in Roger Chartier (ed.), A History of Private Life, vol. 3, English translation (Cambridge, MA and London: Harvard University Press, 1989), pp. 546-548.

21. Carmel Cassar, 'The First Decades of the Inquisition: 1546-1581', Hyphen-A fournal of Melitensia and the Humanities, 4/6, 1985, pp. 223-227.

22. Michael Fsadni, Id-Dumnikani fir-Rabat u fil-Birgu sa l-1620 (Malta: Il-Hajja, 1974), pp. 218-220.

23. Jean Delumeau, Catholicism between Luther and Voltaire: A New View of the Counter-Reformation, English translation (London: Burns \& Oates, 1977), pp. 40-42, 199-202.

24. Delumeau, Catholicism between Luther and Voltaire, pp. 40-42.

25. Joseph Brincat, 'Language and Demography in Malta: The Social Foundations of the Symbiosis between Semitic and Romance in Standard Maltese', in Stanley Fiorini and Victor Mallia-Milanes (eds), Malta. A Case Study in International Cross-Currents (Malta: Malta University Publications, 1991), p. 100.

26. Oliver Friggieri, 'The Search for a National Identity in Maltese Literature', in Victor Mallia-Milanes (ed.), The British Colonial Experience 1800-1964: The Impact on Maltese Society (Malta: Mireva Publications, 1988), p. 289. Yet Dominic Cutajar asserts that, 'the artistic tempo quickened, especially after 1565 when a languishing Gothic tinged sensibility was overlain by newer Mannerist aesthetic considerations'. Thus it seems that Renaissance art was never really a dominant mode of expression in Malta. Dominic Cutajar, 'Seventeenth and Eighteenth Century Art in Malta', in Mario Buhagiar (ed.), Marian Art During the Seventeenth and Eighteenth Centuries (Malta: Printwell, 1983), p. 12.

27. 'maxime in quista nova cita (Birgu) unde per la frequentia deli Italici, homines et donni mischiando 
lo vulgare Italico con lo Maltese come dire, 'Esse nicallihe franca o franc' (Now I leave her or him free) referred to when freeing a slave. Godfrey Wettinger, The fews of Malta in the Late Middle Ages (Malta: Midsea Books Ltd, 1985) p. 167; CAM, CEM, AO, vol. 36, p. 46v.

28. Brincat, 'Language and Demography in Malta', p. 96.

29. Alfredo Mifsud, 'Malta al sovrano nel 1419', La diocesi - Bollettino ufficiale ecclesiastico di Malta, 2, 1918, pp. 243-248; Joseph Cassar Pullicino, 'L-Eqdem Kitba bit-Taljan f'Malta' (Malta: mimeograph, 1966), pp. 1-3.

30. Pompeo Falcone, 'Una "Relazione di Malta" sulla fine del Cinquecento', Archivio Storico di Malta, 4/1, 1933, p. 35; Carlo Anonio Vianello, 'Una Relazione inedita di Malta nel 1582', Archivio Storico di Malta, 7/3, 1936, p. 291. Giacomo Capello, representative of the Venetian Senate in 1716, asserted that the townswomen, 'Quasi tutte parlano l'Italiano, con una cantilena genovese, ma con mischiarvi qualche parola barbara (that is, Maltese) e con una gorga fiera, che spiace'. Victor Mallia-Milanes (ed.), Descrittione di Malta anno 1716-A Venetian Account (Malta: Bugelli Publications, 1988), p. 57; Count Camillo Spreti goes even further. He states that the citizens, l'Italiano poco l'intendono, e meno lo parlano, benché sia il linguaggio più frequentato da loro. $\mathrm{N}$ (ational) L(ibrary of) M(alta) Libr(rary), vol. 1202, p. 196.

31. Carmel Cassar, 'The Reformation and Sixteenth-Century Malta', Melita Historica, 10/1, 1988, pp. 51-68; cf. CAM A(rchives of the) I(nquisition of) M(alta), Crim(inal Proceedings), vol. 144, case 7, pp. 94v-95, 30 April 1579.

32. Brincat, 'Language and Demography in Malta', pp. 96, 98.

33. NLM, Univ(ersità Archives), vol. 15, p. 267v; cf. Wettinger and Fsadni, L-Ghanja tà Pietru Caxaru, pp. 27-32.

34. NLM Univ., vol. 14, p. 506; ibid., p. 28.

35. NLM Univ., vol. 15, p. 468. This petition helps to reveal the existence of an urban versus peasant dichotomy as early as the late sixteenth century.

36. Falcone, 'Una "Relazione di Malta”', p. 35; Vianello, 'Una relazione inedita', p. 291.

37. Manlio Cortelazzo, 'Il contributo del veneziano e del greco all lingua franca', in Hans-Georg Beck, Manoussos Manoussacas and Agostino Pertusi (eds), Venezia. Centro di mediazione tra Oriente e Occidente (secoli $X V-X V I$ ). Aspetti e problemi, vol. 2 (Florence: Leo S. Olschki Editore, 1977), p. 528; Henry Kahane, Renée Kahane and Andreas Tietze, The Lingua Franca in the Levant: Turkish Nautical Terms of Italian and Greek Origin (Urbana, IL: University of Illinois Press, 1958), pp. 3-5.

38. Cortelazzo, 'Il contributo del veneziano', p. 531.

39. Louis Coutelle, 'Grec, grechesco, lingua franca', in Hans-Georg Beck, Manoussos Manoussacas and Agostino Pertusi (eds), Venezia. Centro di mediazione tra Oriente e Occidente (Secoli XV-XVI). Aspetti e problemi, vol. 2 (Florence: Leo S. Olschki Editore, 1977), p. 539, elaborates on the lessico mediterraneo type of lingua franca by an analysis of the Greek case.

40. In August 1617, Margarita Bonnici sive La Bruna stated that among other remedies for love magic, Margarita Bertone advised her to mix four pepper grains and a herb called reheuma in Maltese or musco marino in franco (i.e. lingua franca) or Italian. CAM, AIM, Crim., vol. 40A, p. $161 \mathrm{v}$. Such indications help to confirm the widespread use of lingua franca among the lower echelons of the Harbour area at least since the early seventeenth century.

41. Catherina wife of Vincentio Xerri reported that, Minichella con furia et collera iniuro a decto suo marito dicendoli cornuto ... et molti altri iniuri quali io non posso sapere perchè non intendo della lingua Italiana stando che lei parlava Italiano (With fury and anger Minichella offended her husband by calling him 'horned' ... and many other insults which I could not know because I do not understand the Italian language since she spoke in Italian). CAM, CEM, AO, vol. 480, p. 115, 21 October 1602.

42. Michaelis Antonii Vassalli, Ktyb yl Klym Malti Mfysser byl-Latin u byt-Taljan sive Dictionum Melitense ... sive Liber Dictionum Melitensium ... Lexicon Melitense Latino-Italum (Rome: Antonio Fulgoni, 1796), pp. xvi-xix.

43. Frans Ciappara, Marriage in Malta in the Late Eighteenth Century (Malta: Associated News, 1988), p. 16.

44. Jack Goody, The Logic of Writing and the Organization of Society (Cambridge: Cambridge University Press, 1986), p. 121.

45. Jack Goody, The Interface between the Written and the Oral (Cambridge: Cambridge University Press, 1987), p. 164.

46. Roger Chartier, 'The Practical Impact of Writing', in Roger Chartier (ed.) A History of Private Life, vol. 3, p. 123. 
47. Piero Camporesi, Bread of Dreams. Food and Fantasy in Early Modern Europe, English translation (Cambridge, Polity Press, 1989), p. 65.

48. Gurevich, Medieval Popular Culture, p. xiv.

49. Gurevich, Medieval Popular Culture, p. 37.

50. Kirsten Hastrup, Culture and History in Medieval Iceland. An Anthropological Analysis of Structure and Change (Oxford: Clarendon Press, 1985), especially pp. 221-228; Keith Harrison, The Framezwork of Anglo-Saxon History to A.D. 900 (Cambridge: Cambridge University Press, 1976), p. 52.

51. Peter Burke, Popular Culture in Early Modern Europe (Aldershot: Wildwood House, 1978), pp. 23-29.

52. Max Weber, The Theory of Social and Economic Organisation, A.R. Henderson and Talcott Parsons (eds) (London: William Hodge \& Co., 1947), pp. 329-341.

53. Dominic Cutajar, 'St John's Church', in Giovanni Mangion (ed.), Maltese Baroque (Malta: Ministry of Education, 1989), p. 33.

54. Cutajar, 'Seventeenth and Eighteenth Century Art', p. 14; Dominic Cutajar, 'Caravaggio in Malta. His Works and His Influence', in Philip Farrugia Randon (ed.), Caravaggio in Malta (Malta: Mid-Med Bank Ltd., 1989), p. 13.

55. Mario Buhagiar, 'Baroque Painting in Malta', in Giovanni Mangion (ed.), Maltese Baroque (Malta: Ministry of Education, 1989), p. 37.

56. By the early eighteenth century, the intellectual approach of Roman Baroque was intensified through the presence of the French painter Antoine de Favray (1706-1798). Buhagiar, 'Baroque Painting in Malta', p. 38.

57. Bonamico was a Maltese physician who graduated from Aix-en-Provence and continued his studies at Leyden, Paris, Louvain and Amsterdam. Bonamico was a man of letters similar to the filosofi-scienzati who flourished in Italy at the time. Giovanni Mangion, 'Baroque Literature', in Giovanni Mangion (ed.), Maltese Baroque (Malta: Ministry of Education, 1989), p. 95.

58. By the end of the sixteenth century, two musical cappelle were firmly established, one at St John's in Valletta and the other at the Mdina Cathedral. Musical standards in Malta had risen to a very high level. Joseph Vella, 'Maltese musical Baroque', in Giovanni Mangion (ed.), Maltese Baroque (Malta: Ministry of Education, 1989), pp. 46-47.

59. Vincenzo Laurenza suggests that the feast was introduced in Malta by Italian Grand Master Zondadari (1720-1722). Vincenzo Laurenza, 'Calendimaggio settecentesco a Malta', Archivum Melitense, 2, 1913, pp. 187-195. Yet, the Maltese eighteenth century folklorist and linguist Canon Agius de Soldanis recalled how a poem in Maltese written by Bonamico to honour Grand Master Nicolas Cottoner (1663-1680) was meant to be recited during the Calendimaggio. Agius de Soldanis reproduces the sonnet formed in 16 verses. NLM Libr., vol. 144, p. 108.

60. Joseph Eynaud, 'Teatro e folklore a Malta nel secolo decimottavo', Melita Historica, 6/2, 1973, pp. 153-154.

61. Joseph Cassar-Pullicino, Studies in Maltese Folklore (Malta: Malta University Publication, 1976), p. 24.

62. Peter Burke, Popular Culture in Early Modern Europe, p. 270.

63. Joseph Aquilina, Papers in Maltese Linguistics (Malta: Malta University Publication, 1961), pp. 57-58.

64. Mangion, 'Baroque Literature', pp. 94-95.

65. Francesco Saverio Farrugia, Discorsi accademici (Malta: Government Press, 1778), pp. 7-10.

66. Carmel Cassar, Society, Culture and Identity in Early Modern Malta (Malta: Mireva Publications, 2000), pp. 182-198.

67. NLM Libr., vol. 140, pp. 16v-17; Anthony T. Luttrell, 'Gerolamo Manduca and Gian Francesco Abela: Tradition and Invention in Maltese Historiography', Melita Historica, 7/2, 1977, pp. 129130.

68. Baron Jean Carlsroon Du Mont, A New Voyage in the Levant: Containing an Account of the Most Remarkable Curiosities in Germany, France, Italy, Malta and Turkey, with Historical Observations Relating to the Present and Ancient State of those Countries, English translation, 3rd edition (London: T. Goodwin, M. Wotton and B. Took in Fleet street; J. Walthoe in the Middle-Temple; and R. Parker under the Royal Ex[ch] ange, 1702), pp. 138-139.

69. Cortellazzo, 'Il contributo del veneziano', p. 528.

70. Gian Pier Francesco Agius de Soldanis, Della lingua punica presentemente usata dai maltesi ... ovvero nuovi documenti li quali possono servire di lume all'antica lingua etrusca ... (Rome: Generoso Salomone, 1750), p. 43. 
71. Agius de Soldanis, Della lingua punica, p. 17 where the author referred to a number of mideighteenth century Knights of the Order, who knew Maltese. Agius de Soldanis mentioned several dignitaries of the Order who could speak Maltese so fluently that one could easily mistake them for Maltese. The Prior of the Conventual Church Fra Melchior Alpheran and Fra Count Remisching were among the deceased members of the Order who had acquired Maltese. He further implied that by writing a grammar he hoped to enable any gentlemen to learn Maltese with ease. Agius De Soldanis, Della lingua punica, pp. 62-63.

72. Vassalli, Ktyb yl Klym, p. xvi. The term 'diglossia' has been applied by Charles A. Ferguson when both a standard language and a regional dialect are used. 'Many speakers use their local dialect at home or among family, or friends, of the same dialect area, but use the standard language in communicating with speakers of other dialects or on public occasion'. Charles A. Ferguson, 'Diglossia', in Anwar S. Dil (ed.), Language Structure and Language Use. Essays by Charles A. Ferguson (Stanford, CA: Stanford University Press, 1971), p. 1.

73. NLM Libr., vol. 1202, vi diranno alcuni termini arabi, che voi non intenderete, e quello che è peggio, in presenza vostra, essi molte volte parleranno con altri Maltesi della loro compagnia, p. 196.

74. Henry Frendo, 'Language and Nationality in an Island Colony', Canadian Review of Studies in Nationalism, 3/1, 1975, pp. 26-27.

75. Vassalli, Ktyb yl Klym, pp. xix-xxi.

76. Gian Francesco Abela, Della descrittione di Malta isola nel mare siciliano ... (Malta: Paolo Bonacota, 1647), pp. 258-259.

77. Abela wrote the Della descrittione di Malta (1647); Domenico Magri, Breve racconto del viaggio al Monte Libano (Rome, 1655 and Viterbo, 1664); Giovan Francesco Buonamico, wrote his Memorie dei viaggi ... dall'anno 1657 al 1666 (1672) NLM Libr. ms. Mangion, 'Baroque literature', pp. 84-92.

78. Agius De Soldanis reproduced the sonnet formed in 16 verses. NLM Libr., vol. 144, p. 108.

79. Giovanni Mangion, 'La letteratura barocca a Malta', fournal of the Faculty of Arts, 4/4, 1971, p. 300.

80. N. Postman, 'The Politics of Reading', in Nell Keddie (ed.), Tinker, Tailor ... the Myth of Cultural Deprivation (Harmondsworth: Penguin, 1973), p. 88.

81. Cassar, 'The Reformation and Sixteenth Century Malta', pp. 65-66.

82. Basing himself on the Acts of the Apostles, Abela propagated the view that Malta was christianised by St Paul, who was shipwrecked on the island on his way to Rome. Abela followed closely the views of the Maltese sixteenth century Jesuit Gerolamo Manduca (1574-1643) who asserted that Malta had never defected from Christianity since the times of St Paul. Della descrittione di Malta, pp. 260-267; cf. Luttrell, 'Gerolamo Manduca and Gian Francesco Abela', pp. 105-132.

83. Anthony D. Smith, The Ethnic Origins of Nations (Oxford: Blackwell, 1986), pp. 49, 137-138.

84. Eugene Weber, Peasants into Frenchmen. The Modernization of Rural France, 1870-1914 (Stanford, CA: Stanford University Press, 1976), especially chapters 6 and 29.

85. Arnold Cassola, 'Regole per la lingua maltese'. The 'nobile, pio, cavaliere francese Thezan' and his 'regole per la lingua maltese' (Malta: Ministry of Education, 1988), p. 5.

86. Agius de Soldanis, Della lingua punica, p. 61.

87. Vassalli, Ktyb yl Klym, p. xix.

88. Vassalli, Ktyb yl Klym, p. xiii.

89. Vassalli, Ktyb yl Klym, p. xxi.

90. Vassalli, Ktyb yl Klym, and Ralph D. Grillo, Dominant Languages. Language and Hierarchy in Britain and France (Cambridge: Cambridge University Press, 1989), p. 24.

91. Hans Kohn, The Idea of Nationalism: A Study in its Origins and Background, 2nd edition (New York: Collier-MacMillan, 1967), pp. 580-581.

92. Ralph D. Grillo, 'Introduction', in Ralph D. Grillo (ed.), Nation and State in Europe. Anthropological Perspectives (London: Academic Press, 1980).

93. A.B. Philip, 'European Nationalism in the Nineteenth and Twentieth Centuries', in Rosalind Mitchinson (ed.), The Roots of Nationalism: Studies in Northern Europe (Edinburgh: John Donald Publishers, 1980), p. 5.

94. Benedict Anderson, Imagined Communities. Reflections on the Origin and Spread of Nationalism (London and New York: Verso, 1983), pp. 45, 81.

95. Ibid., p. 49.

96. Marshall McLuhan, Understanding Media. The Extensions of Man (London: Sphere Books, 1967), p. 189. 
97. Carlo Cipolla, Literacy and Development in the West (Harmondsworth: Pengiun, 1969), pp. 101102.

98. Although Maltese is classified as a Semitic language, and in spite of some attempts-in the nineteenth century - to introduce a Semitic script it has always been written in Latin script. The first literary work written in Maltese so far discovered-the fifteenth century cantilena by Pietro Caxaro-was written in Latin script.

99. Henry Frendo, 'Maltese Colonial Identity: Latin Mediterranean or British Empire', in Victor Mallia-Milanes (ed.), The British Colonial Experience 1800-1964: The Impact on Maltese Society (Malta: Mireva Publications, 1988), p. 186.

100. Ibid., p. 193.

101. Ibid., pp. 204-206.

102. Gerald Strickland, Malta and the Phoenicians, 2nd ed. (Malta: Progress Press, 1969 [1st ed. published 1921]), pp. 7-8, 12, 25. 